\title{
MULTIMEDIA PEMBELAJARAN INTERNET DASAR DAN LANJUTAN UNTUK E-LEARNING LKP PALCOMTECH PALEMBANG
}

\author{
Yasermi Syahrul $^{1}$, Ongki Anggara ${ }^{2}$ \\ ${ }^{1}$ Dosen Program Studi Desain Komunikasi Visual Politeknik PalComTech, \\ ${ }^{2}$ Mahasiswa Program Studi Sistem Informasi STMIK PalComTech \\ Politeknik - STMIK PalComTech, Palembang \\ 1yasermi_syahrul@palcomtech.ac.id, ºngkianggara@gmail.com
}

\begin{abstract}
LKP PalComTech Kilkenny is currently learning-based systems have implemented e-Learning to support activities by teachers (instructor) teaching for students/learning-based system i. e-learning being used has some drawbacks, among them: the learning materials used in e-learning is still using text, so the lack of interest of the students to open the subject matter. Therefore, to improve the quality of learning is more effective, fun, and easy to understand, then the learning materials are needed in the form of a video.

The process of making learning materials in using multiple stages namely observation, interviews, and the study of literature. Then continue to use the method of the life cycle of the development of Multimedia (MDLC) which consists of six stages: concept, design, collect content material, Assembly, testing, and distribution. Based on the results of the testing method using alpha obtained the conclusion that learning materials producing video animations, dubing backsound music, and with criteria that can be used in helping students in the process of learning activities.
\end{abstract}

Keywords: Multimedia, Video, design

\section{PENDAHULUAN}

Teknologi multimedia telah menjanjikan potensi besar dalam merubah cara seseorang untuk belajar, untuk memperoleh informasi, menyesuaikan informasi dan sebagainya. Menurut Tay, dalam Pendiartawan (2016), multimedia sebagai kombinasi teks, grafik suara, animasi, dan video. Mufiqon (2012) menjelaskan penerapan multimedia pembelajaran pada proses belajar mengajar dimaksudkan agar belajar menjadi menjadi lebih efektif, lebih efisien, lebih luas, lebih cepat dan lebih bermakna bagi yang belajar, khusus nya siswa. Untuk itu ada produk yang sengaja dibuat serta dimanfaatkan dalam pembelajaran. Seiring berkembangnya teknologi yang semakin pesat, sistem pembelajaran yang dahulu menggunakan modul pembukuan, kini sudah berkembang menggunakan teknologi $e$ learning yang dapat di akses dimanapun dan kapanpun melalui internet. E-learning atau pembelajaran elektronik sebagai salah satu proses pembelajaran yang memanfaatkan teknologi informasi berupa komputer yang dilengkapi dengan sarana telekomunikasi dan memanfaatkan multimedia pembelajaran (grafis, audio, video, dan animasi).

Lembaga Kursus dan Pelatihan (LKP) PalComTech berdiri sejak tahun 2003, dan saat itu menerapkan sistem 100\% internet $100 \%$ praktek. Sudah 13 tahun mengembangkan lembaga pendidikan IT ini, LKP PalComTech telah meluluskan ribuan siswa/i terampil dengan mendapatkan penghidupan dan karir yang lebih baik. LKP 
PalComTech telah hadir di 5 kota di wilayah Sumatera Bagian Selatan yaitu: Palembang, Jambi, Baturaja, Lahat, dan Prabumulih. Disamping itu telah didirikan juga lembaga pendidikan formal dalam bentuk Politeknik dan Sekolah Tinggi Manajemen Informatika dan Komputer (STMIK). Metode pembelajaran dikembangkan dengan lebih efektif menerapkan teknologi e-learning yang membuat daya tangkap siswa/i menjadi 3 kali lebih cepat dan lebih mahir.

LKP PalComTech Palembang saat ini telah menerapkan sistem pembelajaran berbasis e-learning untuk menunjang aktivitas mengajar oleh tenaga pengajar (instruktur) kepada siswa/i. Tetapi, menurut Bapak Kasmoni (35) selaku Manajer R \& D (Research \& Development) LKP PalComTech Palembang pada tanggal 1 November 2016, bahwa sistem pembelajaran berbasis e-learning yang digunakan memiliki beberapa kekurangan, diantaranya: materi pembelajaran yang digunakan pada e-learning tersebut masih menggunakan teks, sehingga kurangnya minat siswa/i untuk membuka materi pembelajaran tersebut. Oleh sebab itu, untuk meningkatkan kualitas belajar yang lebih efektif, menyenangkan, dan mudah dipahami, maka diperlukan materi pembelajaran dalam bentuk video.

\section{METODE PENELITIAN}

Pembuatan Multimedia Pembelajaran Internet Dasar dan Lanjutan LKP PalComTech Palembang menggunakan beberapa tahapan. Pemilihan model ini didasari atas pertimbangan bahwa model ini dikembangkan dengan landasan teoretis desain pembelajaran. Model ini disusun secara terprogram dengan urutan-urutan kegiatan yang sistematis dalam upaya pemecahan masalah belajar yang berkaitan dengan sumber belajar yang sesuai dengan kebutuhan dan karakteristik pebelajaran. Metode pengumpulan data diantaranya Observasi, Wawancara, dan Studi Pustaka. Kemudian dilanjutkan pada tahap Pembuatannya, penulis menggunakan metode yang sudah menjadi standar dalam pengembangan sebuah proyek multimedia, yaitu metode Multimedia Development Life Cycle (MDLC) Metode ini terdiri dari enam tahapan yaitu: concept, design, collecting content material, assembly, testing, dan distribution.

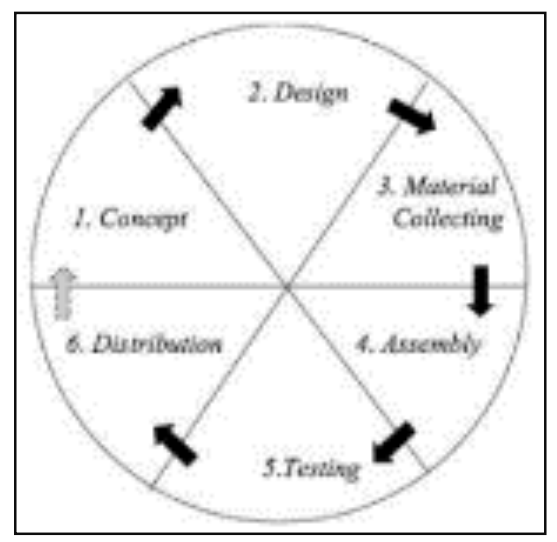

Gambar 1 Metode Multimedia Development Life Cycle (MDLC)

\section{PEMBAHASAN}

A. Tahap Pengumpulan Data

Tahap pengumpulan data dilakukan dengan observasi, wawancara dan study literature. Pertama, observasi dilakukan dengan mengamati materi pembelajaran pada euniversity.palcomtech.com.

Kedua, Wawancara dilakukan langsung dengan Bapak Kasmoni (35) selaku Manajer R \& D (Research \& Development) LKP PalComTech Palembang mengenai sejarah perusahaan, tujuan pembuatan materi pembelajaran, target 
pembelajaran, dan manfaat pembuatan materi pembelajaran baik bagi perusahaan maupun bagi siswa/i PalComTech. Ketiga, study literature merupakan kegiatan mencari informasi yang tujuannya menunjang proses penelitian dengan mempelajari literatur serta membaca sumber-sumber data informasi lainnya yang berhubungan dengan pembahasan.

\section{B. Tahap Pengkonsepan (Consept)}

Menurut Sutopo dalam Pratama (2014), tahap pengkonsepan (concept) adalah tahap untuk menentukan tujuan dan siapa pengguna program (audiens identification). Tujuan dan pengguna akhir program berpengaruh pada nuansa multimedia sebagai pencerminan dari identitas organisasi yang menginginkan informasi sampai pada pengguna akhir.

Berikut tabel konsep "Multimedia Pembelajaran Internet Dasar dan Lanjutan LKP PalComTech Palembang” yang dijelaskan melalui tabel 1.

Tabel 1 Deskripsi konsep

\begin{tabular}{|l|l|}
\hline Judul & $\begin{array}{l}\text { Multimedia Pembelajaran } \\
\text { Internet Dasar dan Lanjutan } \\
\text { LKP PalComTech } \\
\text { Palembang. }\end{array}$ \\
\hline Jenis Multimedia & $\begin{array}{l}\text { Multimedia Pembelajaran. } \\
\text { Tujuan }\end{array}$ \\
$\begin{array}{l}\text { Meningkatkan kualitas } \\
\text { materi pembelajaran yang } \\
\text { sebelumnya menggunakan } \\
\text { teks dan gambar, dengan } \\
\text { adanya materi dalam bentuk } \\
\text { video ini dapat } \\
\text { meningkatkan kualitas } \\
\text { belajar yang lebih efektif, } \\
\text { menyenangkan, dan mudah } \\
\text { dipahami. }\end{array}$ \\
\hline Sasaran & $\begin{array}{l}\text { Target utamanya adalah } \\
\text { seluruh warga PalComTech. }\end{array}$ \\
\hline
\end{tabular}

\begin{tabular}{|l|l|}
\hline Audio & $\begin{array}{l}\text { Format audio yang } \\
\text { digunakan adalah *.mp3. }\end{array}$ \\
\hline Video & $\begin{array}{l}\text { Menggunakan dua tempat } \\
\text { pengambilan video. Ruang } \\
\text { photography menggunakan } \\
\text { background green screen, } \\
\text { dan di ruang SpeakOut } \\
\text { menggunakan background } \\
\text { televisi, hasilnya dalam } \\
\text { format*.mp4. }\end{array}$ \\
\hline
\end{tabular}

C. Tahap Perancangan (Design)

Menurut Purwanto (2016), metode berbasis storyboard merupakan visual test yang pertama-tama dari gagasan dimana secara keseluruhan dapat dilihat apa yang dapat disajikan. Kontribusi dari tahap ini adalah menghasilkan sketsa tampilan yang akan dibuat pada tahap selanjutnya, dan juga bisa sebagai pedoman atau alur cerita yang akan dibuat.

Pembuatan storyboard menggunakan pensil, penghapus, dan kertas A4 yang digambar secara manual. Pembuatan storyboard ini dibagi kedalam enam tabel storyboard salah satunya dijelaskan melalui Tabel 1.

Tabel 2 Storyboard Intro dan Materi Pertemuan 1

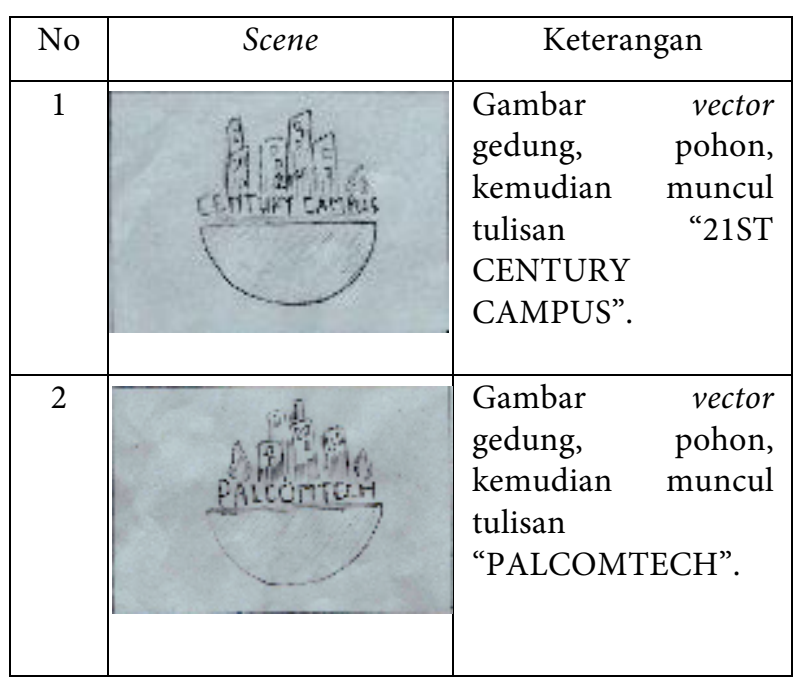




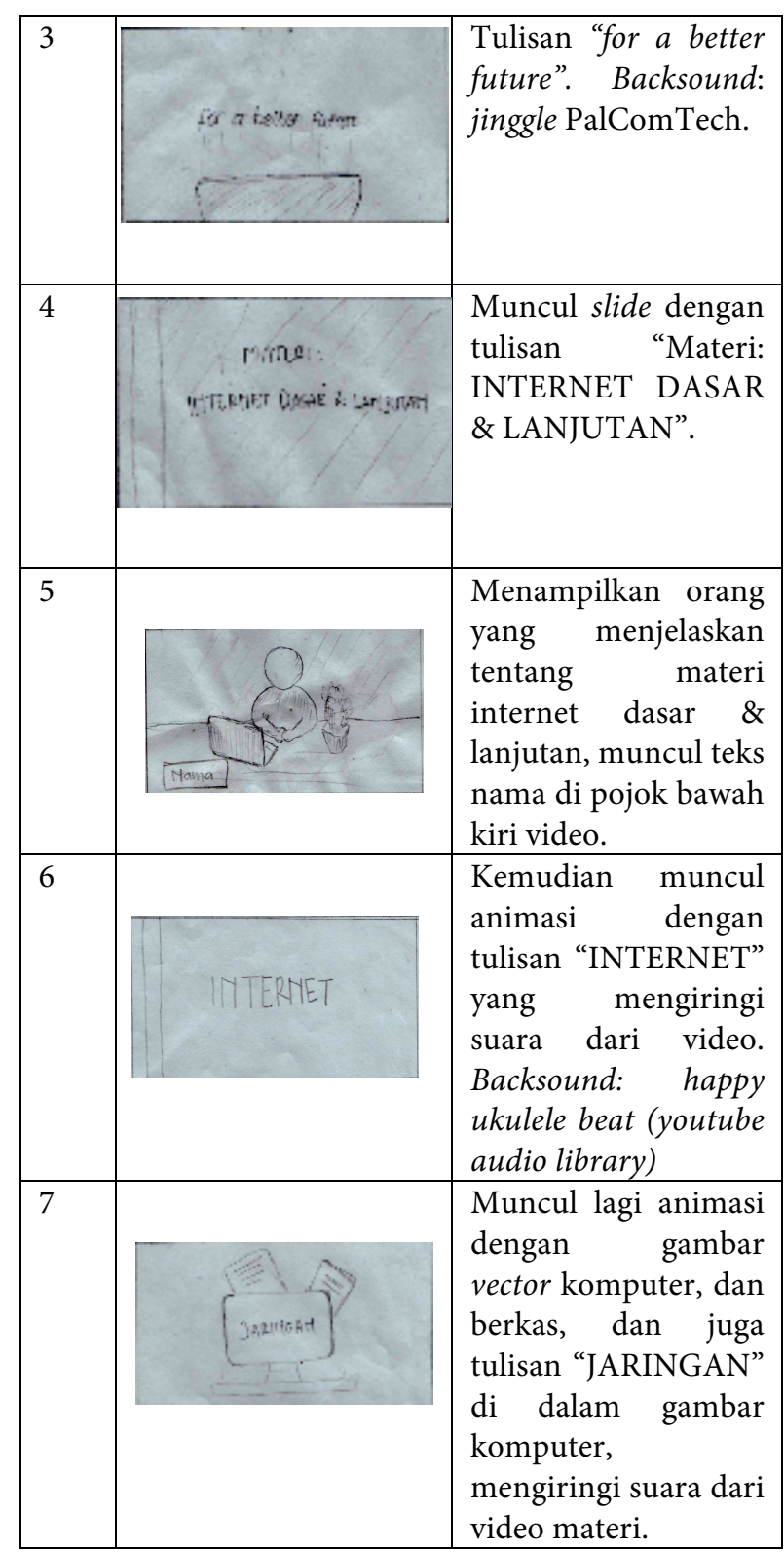

D. Tahap Pengumpulan Materi (Material Collecting)

Menurut Sutopo dalam Pratama (2014), material collecting adalah tahap pengumpulan bahan yang sesuai dengan kebutuhan yang dikerjakan. Bahan-bahan tersebut antara lain clip art, foto, animasi, video, audio dan lain lain yang diperoleh secara gratis atau dengan pemesanan kepada pihak lain sesuai dengan rancangan.
Materi yang perlukan dalam tahap pengumpulan materi adalah perangkat keras (hardware) satu unit laptop dengan spesifikasi: Processor Core i3 @2,3 GHz,Vga intel HD 3000, Harddisk 300 Gb, Memory (RAM) $4 \mathrm{~Gb}$, Scanner untuk memindai gambar storybord, Kamera DSLR untuk pengambilan video, Smartphone untuk mengambil suara dari video dan mengambil suara untuk perekam desktop, Background green screen untuk mengubah gambar background video dan Lighting untuk menambah pencahayaan video.

Kemudian dibutuhkan perangkat lunak (software) Windows 864 bit sebagai sistem operasi, Adobe After Effects CS3 untuk mengganti background green screen dan membuat animasi, Adobe Premiere CS6 digunakan untuk penggabungan video dan audio menjadi satu (composite), Freemake Video Converter digunakan untuk mengonversi file, Camtasia Studio 8 digunakan untuk merekam aktivitas desktop, Adobe Illustrator CS6 untuk pengeditan gambar vector dari freepik.com.

Pembuatan "Multimedia Pembelajaran Internet Dasar dan Lanjutan LKP PalComTech Palembang" ini, penulis menggunakan foto dan beberapa gambar-gambar vector sebagai referensi dalam pembuatan video. Berikut gambar yang penulis gunakan dapat dilihat melalui Tabel 2.

Tabel 3 Foto dan gambar pada tahapan material collecting

\begin{tabular}{|c|l|}
\hline Gambar & \multicolumn{1}{|c|}{ Keterangan } \\
\hline & $\begin{array}{l}\text { Gambar gedung digunakan } \\
\text { untuk background video. } \\
\text { Sumber: google.co.id, } \\
\text { diakses pada tanggal 01 } \\
\text { Agustus 2016. }\end{array}$ \\
\hline
\end{tabular}




\begin{tabular}{|l|l|}
\hline & $\begin{array}{l}\text { Gambar vector pohon, } \\
\text { digunakan untuk animasi } \\
\text { bumper. Sumber: } \\
\text { freepik.com, diakses pada } \\
\text { tanggal 01 Agustus 2016. }\end{array}$ \\
\hline & $\begin{array}{l}\text { Gambar vector mobil warna } \\
\text { merah, digunakan untuk } \\
\text { animasi bumper. Sumber: } \\
\text { freepik.com, diakses pada } \\
\text { tanggal 01 Agustus 2016. }\end{array}$ \\
\hline & $\begin{array}{l}\text { Gambar vector mobil warna } \\
\text { ungu, digunakan untuk } \\
\text { animasi bumper. Sumber: } \\
\text { freepik.com, diakses pada } \\
\text { tanggal 01 Agustus 2016. }\end{array}$ \\
\hline
\end{tabular}

Pembuatan"Multimedia Pembelajaran Internet Dasar dan Lanjutan LKP PalComTech Palembang" ini, penulis menggunakan beberapa audio yang dijelaskan pada tabel 4 .

Tabel 4 Tabel audio pada tahap material collecting

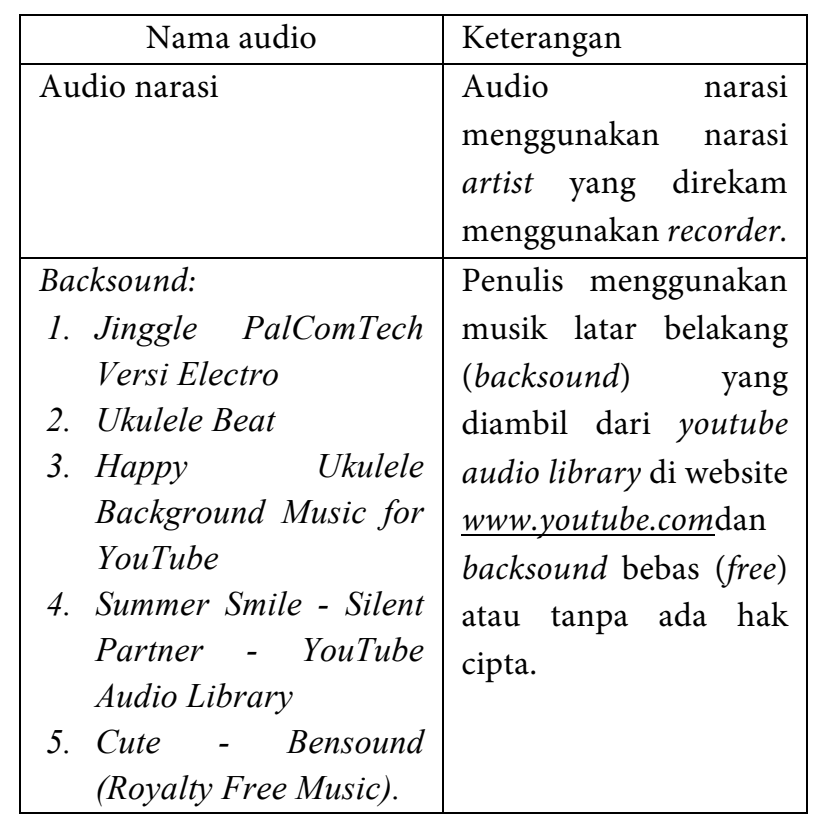

E. Tahap Pembuatan (Assembly)

Tahapan pembuatan (assembly) merupakan tahapan pengimplementasian dari tahap pengkonsepan, tahap desain, dan pengumpulan materi. Penulis membuat video materi berdasarkan storyboard yang telah dibuat pada tahap desain.

Berikut adalah tahapan dalam pembuatan "Multimedia Pembelajaran Internet Dasar dan Lanjutan.

a. Tahapan pembuatan animasi bumper video

Bumper digunakan untuk intro awal dari sebuah video materi dan dibuat menggunakan Adobe After Effects CS3.

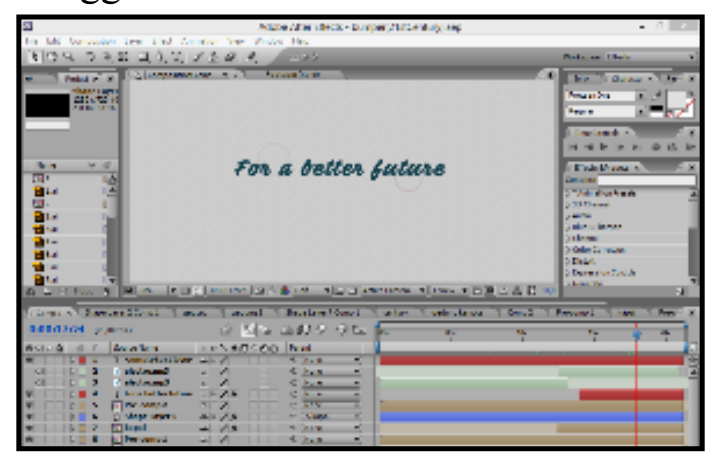

Gambar 2 Pembuatan bumper video for a better future

Berdasarkan gambar 2 pembuatan bumper video for a better future, terdapat background menggunakan efek venetian blinds sehingga tampak garis-garis miring. Muncul setengah lingkaran menggunakan animasi rotation. Muncul gambar vector roket yang dibuat menggunakan pen tool dan menggunakan animasi position. Kemudian muncul teks for a better future menggunakan animasi scale. 
b. Tahapan pembuatan animasi slider video Pada tahapan ini animasi slider digunakan untuk transisi dari satu video ke video lain.

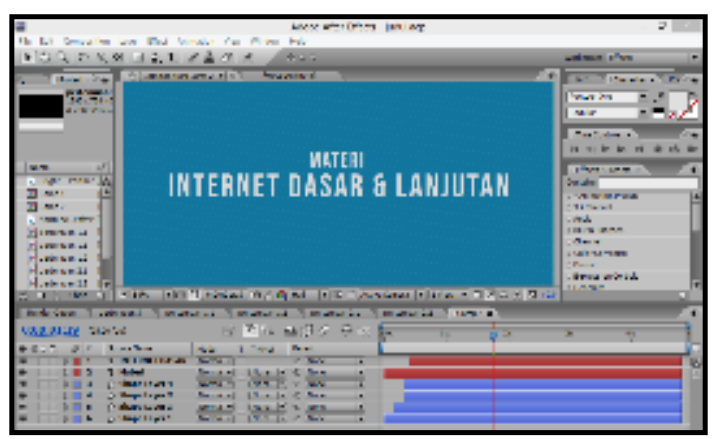

Gambar 3 Pembuatan animasi slider judul

Berdasarkan gambar 5 pembuatan animasi slider, muncul tiga gambar persegi menggunakan animasi position dari kanan ke kiri dan gambar persegi terakhir menggunakan efek venetian blinds. Kemudian muncul teks menggunakan animasi scale.

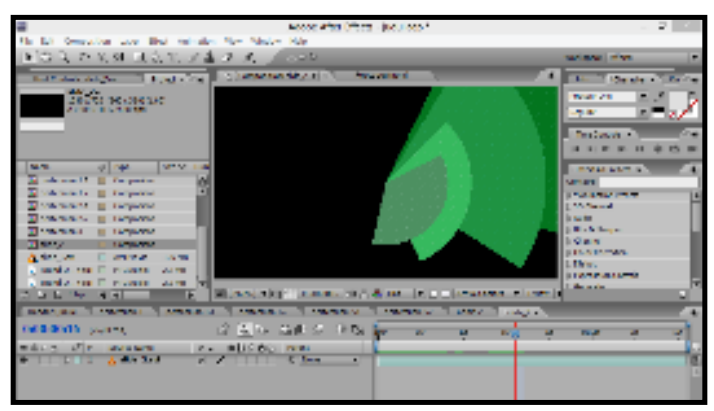

Gambar 4 Pembuatan animasi slider transisi

Berdasarkan gambar 4 pembuatan animasi slider transisi, awalnya adalah bentuk bulat total yang berbeda bentuk dan warna dibuat menggunakan shape tool, kemudian diberi efek dan animasi trim path dan efek venetian blinds sehingga tampak garis-garis miring. c. Tahapan pembuatan animasi teks nama Animasi teks nama digunakan untuk memberikan informasi nama penyampai materi (artist). Pembuatan animasi teks nama, penulis menggunakan Adobe After Effects CS3.

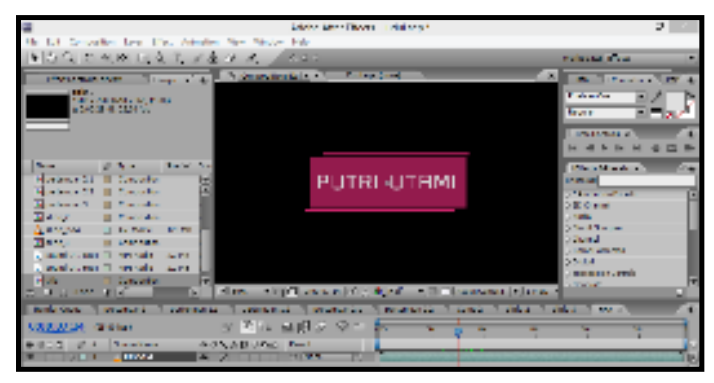

Gambar 5 Pembuatan animasi teks nama

Berdasarkan gambar 5 pembuatan animasi teks nama, terdapat satu buah persegi panjang dengan tulisan "Putri Utami" yang merupakan nama penyampai materi dibuat menggunakan shape tool, text tool dengan font masque dan menggunakan animasi scale. Posisi atas dan bawah teks nama terdapat garis dibuat menggunakan pen tool, kemudian menggunakan animasi trim path.

d. Tahapan mengganti background video

Setelah pengambilan gambar video yang berlatar belakang green screen, penulis menggunakan Adobe After Effects CS3 untuk mengganti background. 


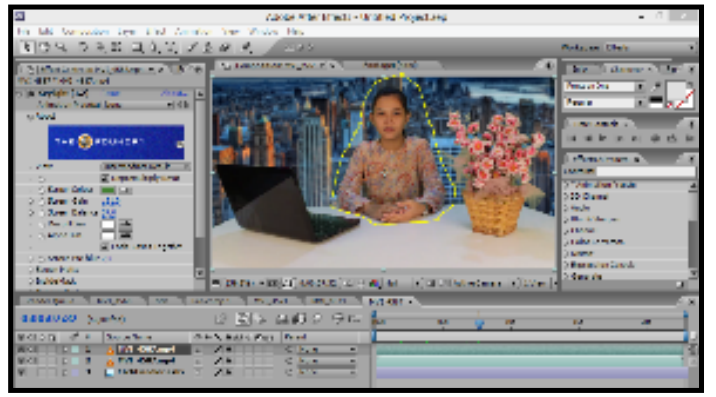

Gambar 6 Penggantian background video

Berdasarkan gambar 6 penggantian background video, untuk mengganti background green screen menggunakan keylight (2.1) yang terdapat di effects \& presets. Kemudian background green screeen diganti menjadi gambar gedung, dan diberi efek fast blur.

e. Tahapan pembuatan animasi pendukung Animasi pendukung digunakan untuk memperjelas materi yang diberikan oleh penyampai materi (artist), animasi yang digunakan adalah animasi 2D.

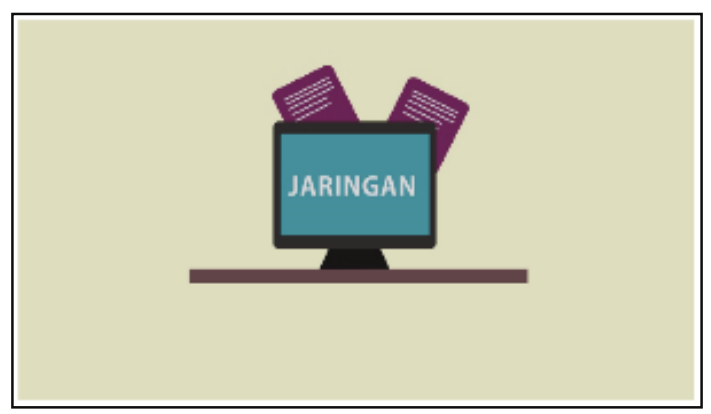

Gambar 7 Pembuatan animasi jaringan

Berdasarkan gambar 7 pembuatan animasi jaringan, menampilkan gambar komputer, dibuat menggunakan shape tool, kemudian diberi animasi scale, position dan teknik masking.

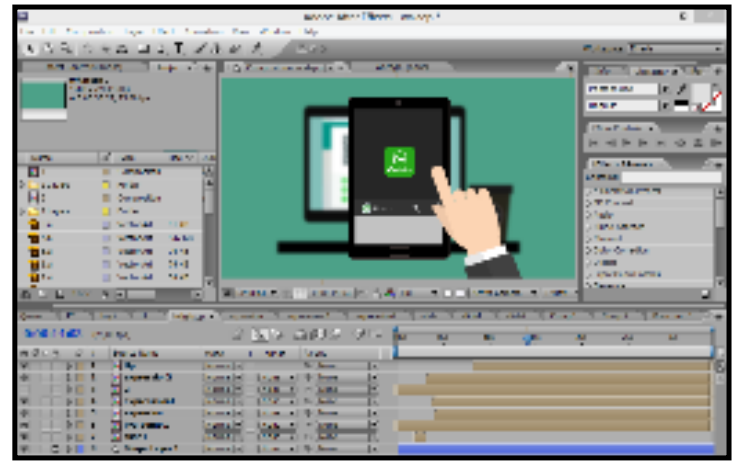

Gambar 8 Pembuatan animasi cara scan code

Berdasarkan gambar 8 pembuatan animasi WhatsApp, terdapat komputer dengan gambar code WhatsApp dan juga gelas kopi. Dibuat menggunakan shape tool kemudian diberi animasi scale, position, dan teknik masking.

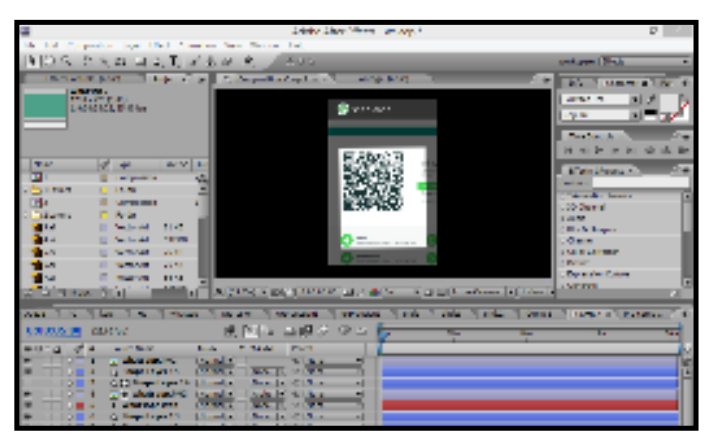

Gambar 9 Pembuatan animasi cara scan code

Berdasarkan gambar 9 pembuatan animasi cara scan code, terdapat sebuah smartphone yang dibuat menggunakan shape tool kemudian diberi animasi scale.

f. Tahapan konversi video

Konversi video digunakan untuk mengubah format *.AVI hasil render dari After Effects menjadi format *.mp4. Selain itu, konversi juga digunakan untuk mengecilkan size video tanpa mengurangi 
kualitas video tersebut. Penulis menggunakan software Freemake Video Converter.

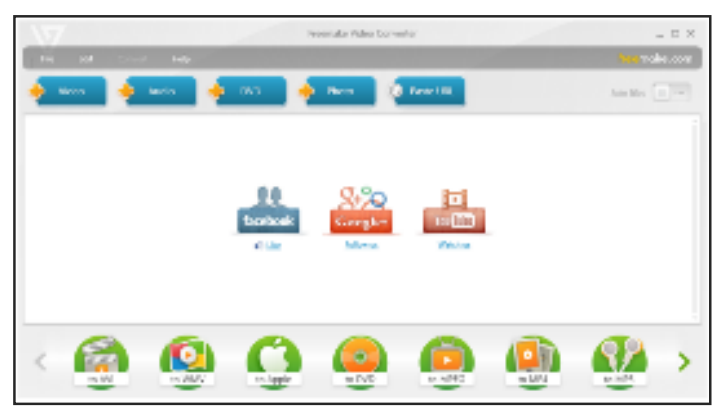

Gambar 10 Tampilan Freemake Video Converter

\section{g. Editing layar desktop}

Camtasia Studio 8 merupakan salah satu software perekam aktivitas desktop yang sudah banyak digunakan, di tahap ini yang menggunakan camtasia studio 8 adalah penyampai materi (artist).

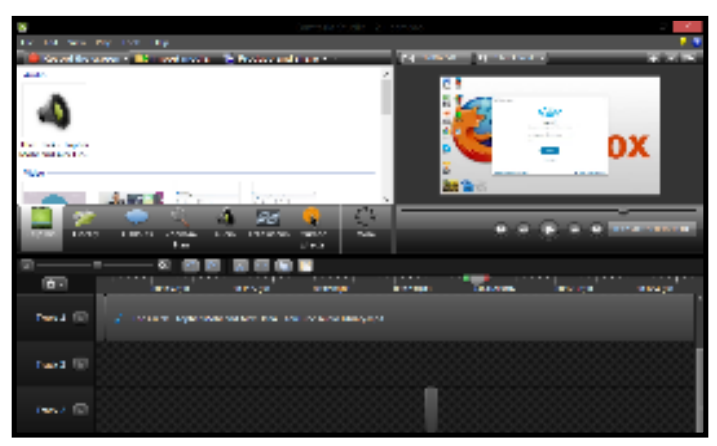

Gambar 11 Editing Camtasia Studio 8

h. Tahapan render After Effect

Tahapan render After Effects merupakan tahapan render animasi bumper video, animasi pendukung, teks nama, penggantian background yang sudah diedit menggunakan Adobe After Effects CS3.

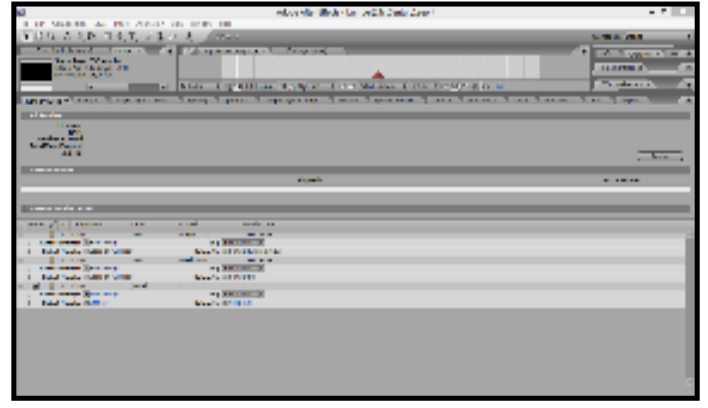

Gambar 12 Tahapan render After Effect

\section{i. Tahapan composite}

Tahapan composite merupakan tahapan penggabungan seluruh materi pembelajaran berdasarkan storyboard dan SAP (Satuan Acara Pengajar). Penulis menggunakan software Adobe Premiere CS6.

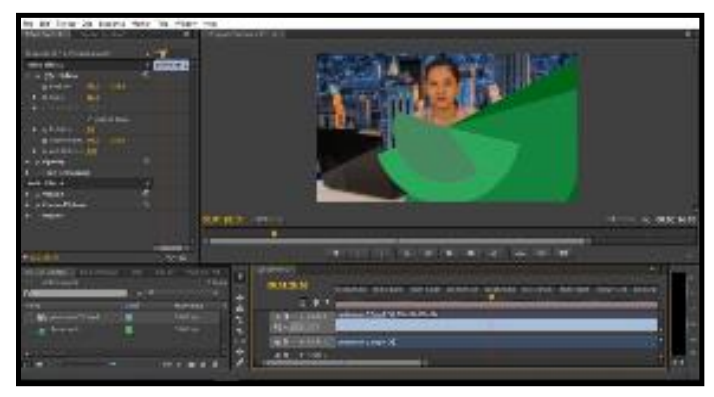

Gambar 13 Tahapan composite dan final render

F. Tahap Pengujian

Tahapan pengujian dilakukan setelah semua tahap selesai dari tahap pembuatan dan seluruh animasi yang telah dibuat. Tahap pengujian ini mempunyai fungsi untuk memastikan bahwa hasil pembuatan animasi multimedia sesuai dengan yang sudah direncanakan. Salah satu hal yang harus diutamakan dalam pembuatan materi pembelajaran ini adalah harus berjalan baik dengan lingkungan user.

Pengujian "Multimedia Pembelajaran Internet Dasar dan Lanjutan LKP PalComTech Palembang" ini, menggunakan metode alpha dengan hasil sebagai berikut. 
Tabel 5 Hasil Pengujian

\begin{tabular}{llc}
\hline No & \multicolumn{1}{c}{ Pengujian } & $\begin{array}{c}\text { Hasil } \\
\text { Pengujian }\end{array}$ \\
\hline $\mathbf{1}$ & Animasi & Ok \\
\hline $\mathbf{2}$ & Dubing & Ok \\
\hline $\mathbf{3}$ & Backsound & $\mathrm{Ok}$ \\
\hline $\mathbf{4}$ & Video & $\mathrm{Ok}$ \\
\hline
\end{tabular}

G. Tahap Pendistribusian

Tahapan distribusi ini akan meghasilkan video berformat *.mp4, dan juga sudah dibagi per pertemuan. Pendistribusian "Multimedia Pembelajaran Internet Dasar dan Lanjutan LKP PalComTech Palembang" akan disimpan di flash memory, kemudian akan disimpan di database melalui system oleh admin $R \& D$ (Research \& Development).

\section{KESIMPULAN}

Berdasarkan pembahasan yang telah dikemukakan pada bab-bab sebelumnya tentang "Multimedia Pembelajaran Internet Dasar dan Lanjutan LKP PalComTech Palembang", dapat menarik kesimpulan diantaranya:

1. Menghasilkan materi pembelajaran berbentuk video.

2. Materi pembelajaran ini bertujuan untuk membantu proses belajar mengajar menjadi efektif.

3. Materi pembelajaran ini bisa diakses dimanapun dan kapanpun, karena adanya teknologi e-learning yang sudah ada sejak LKP PalComTech berdiri.

Multimedia Pembelajaran Internet Dasar dan Lanjutan LKP PalComTech Palembang ini diharapkan dapat digunakan untuk kebutuhan e-learning LKP PalComTech serta bisa diterima dan mudah dipahami oleh siswa.

\section{DAFTAR PUSTAKA}

[1] Pendiartawan, Kadek, dkk. 2016. Pengembangan Multimedia Pembelajaran Interaktif Dengan Model Addie Pada Mata Pelajaran Ipa Kelas Viii Di Smpn 1 Seririt. e-Journal Edutech Universitas Pendidikan Ganesha Jurusan Teknologi Pendidikan. Vol. 5 No. 2. Hal: 1-11.

[2] Musfiqon, HM. 2012. Pengembangan Media dan Sumber Pembelajaran. Jakarta: Prestasi Pustaka.

[3] Pratama, Wahyu. 2014. Game Adventure Misteri Kotak Pandora. Jurnal Telematika Vol. 7 No.2. Hal: 13-31.

[4] Purwanto, Agus, dan Hanief, Shofwan. 2016. Multimedia Pembelajaran Bahasa Indonesia Untuk Mahasiswa Berbasis Animasi. Seminar Nasional Teknologi Informasi dan Multimedia 2016. ISSN: 2302-3805. Hal: 13-18. 